\title{
Karakteristik Gelombang Laut pada Rencana Pembangunan Breakwater di Pelabuhan Tanjung Adikarto
}

\author{
FITRI SUCIATY, HASAN MURTADHO \\ Program Studi Teknik Sipil, Institut Teknologi Nasional Bandung \\ Email: fitrisuciaty@itenas.ac.id
}

\begin{abstract}
ABSTRAK
Desain breakwater pada pembangunan Pelabuhan Tanjung Adikarto telah beberapa kali mengalami perubahan sejak tahun 2003. Pelaksanaan konstruksi breakwater sisi barat dan sisi timur pada tahun 2007 dan 2008 mengalami kegagalan akibat gelombang tinggi dari Samudera Hindia yang dianggap merusak. Desain review dengan sudut breakwater yang bergeser untuk membuka jalur navigasi dibuat pada tahun 2011 dan proses konstruksinya terhenti pada tahun 2012. Desain tinjauan ketiga dibuat pada tahun 2013 namun hingga saat ini konstruksinya belum dimulai. Berdasarkan laporan Proyek Yogya yang disupervisi oleh TU Delft, diketahui bahwa belum pernah dilakukan penelitian mengenai kondisi hidrodinamika untuk perencanaan pelabuhan. Pada penelitian ini, pemodelan hidrodinamika dan pemodelan transformasi gelombang dilakukan dengan tujuan untuk mengkaji karakteristik gelombang di sekitar breakwater. Pemodelan dilakukan untuk skenario desain tahun 2011 dan desain tahun 2013. Simulasi dilakukan pada bulan bulan Januari (musim barat) dan bulan Juli (musim timur) selama 30 hari guna mengetahui efektifitas dari breakwater dalam meredam gelombang.
\end{abstract}

Kata kunci: breakwater, pemodelan, hidrodinamika, gelombang.

\begin{abstract}
Since 2003, the breakwater design in the development planning for the Tanjung Adikarto Port has changed several times. The construction of the west and east side breakwaters in 2007 and 2008 failed due to high waves from the Indian Ocean which were considered destructive. A review design with a shifted breakwater angle to open the navigation chanel was made in 2011 and the construction also stopped in 2012. The third review design was made in 2013 but the construction has yet to begin. Based on the Yogya Project report supervised by TU Delft, it is known that hydrodynamic conditions have never been assessed for port planning. In this study, hydrodynamic and wave transformation modeling were carried out in order to study the characteristics of the waves around the breakwater. Modeling was carried out for the 2011 design scenario and also for 2013 review design scenario to determine the effectiveness of the breakwater in reducing waves.
\end{abstract}

Keywords: breakwater, modeling, hydrodynamics, wave. 
Fitri Suciaty, Hasan Murtadho

\section{PENDAHULUAN}

Pelabuhan Tanjung Adikarto adalah pelabuhan ikan yang berada di Pantai Glagah yang tepatnya berlokasi di Desa Karangwuni, Kabupaten Kulon Progo, Provinsi Daerah Istimewa Yogyakarta (DIY). Hingga saat ini, Pelabuhan Tanjung Adikarto belum dapat dioperasikan secara optimal sebagaimana tujuan awal pembangunannya. Salah satu penyebabnya yaitu karena adanya permasalahan pada pembangunan breakwater, dimana breakwater tidak berfungsi secara optimal. Hasil paparan dari Balai Besar Sungai (BBWS) Serayu Opak pada tahun 2015, terdapat keruntuhan pada kepala breakwater dan beberapa bagian lengan pada bagian badan breakwater mengalami kerusakan. Pada sisi barat breakwater terjadi gempuran gelombang yang besar dan ganas yang mengakibatkan hilangnya beberapa material inti pada bangunan breakwater (Bhakty, T. E., 2015).

Desain breakwater pada Pelabuhan Tanjung Adikarto pertama kali dibuat pada tahun 2003. Desain tersebut kemudian mengalami perubahan pada tahun 2005. Pada tahun 2007 konstruksi breakwater sisi barat dimulai, namun terjadi kegagalan. Ujung barat breakwater runtuh karena gelombang tinggi dari Samudera Hindia. Pada tahun 2008, desain review dibuat dan pembangunan breakwater sisi timur dimulai. Konstruksi breakwater sisi timur juga terhenti karena terdapat limpasan gelombang yang dianggap terlalu merusak. Pada tahun 2010 kemajuan lebih lanjut dibuat di bidang konstruksi. Sebuah dinding penahan di atas breakwater sisi timur dibuat dan lapisan pelindung untuk lapisan inti dan kepala breakwater dipasang pada breakwater sisi barat. Pada tahun 2011, dilakukan kembali desain review dimana pada desain tersebut sudut breakwater dibuat bergeser untuk membuka jalur navigasi. Konstruksi pemecah gelombang bagian barat dan timur dilanjutkan pada tahun 2011 dan terhenti pada tahun 2012. Desain tinjauan ketiga dibuat pada tahun 2013, namun konstruksi berdasarkan desain ini belum dimulai hingga saat ini. Desain review tahun 2013 merupakan desain penyempurnaan bangunan breakwater dari desain tahun 2011, yaitu dilakukan penambahan panjang breakwater sebesar $\pm 40 \mathrm{~m}$ untuk breakwater sisi barat dan \pm 110 m untuk breakwater sisi timur dari breakwater eksisting.

Berdasarkan laporan Project Yogya yang disupervisi oleh TU Delft dan bekerja sama dengan BBWS Serayu Opak dan Universitas Gadjah Mada pada tahun 2016, diketahui bahwa belum pernah dilakukan penelitian mengenai kondisi hidrodinamika untuk perencanaan pelabuhan. Oleh karena itu, pada penelitian ini kondisi hidrodinamika dan karakteristik gelombang pada kondisi eksisting yaitu desain review tahun 2011 dan desain perencanaan penyempurnaan bangunan breakwater (desain review tahun 2013) dikaji berdasarkan hasil simulasi pemodelan hidrodinamika dan transformasi gelombang di sekitar Pelabuhan Tanjung Adikarto dengan menggunakan open source software model Delft3D (Deltares, 2014). Pemodelan juga dilakukan untuk mengetahui efektivitas dari desain breakwater yang ada berdasarkan reduksi tinggi gelombang.

\section{PEMODELAN HIDRODINAMIKA DAN TRANSFORMASI GELOMBANG}

Pada penelitian ini, pemodelan hidrodinamika dan transformasi gelombang 2-dimensi dilakukan dengan menggunakan Delft-D versi open source software. Sistem pemodelan Delft3D dapat digunakan untuk mensimulasikan perambatan gelombang, kecepatan dan arah arus, transpor sedimen, perubahan morfologi dan juga kualitas air di daerah pesisir, sungai dan muara sungai. Pada penelitian ini, model yang digunakan yaitu Delft3D-FLOW dan Delft3D-WAVE.

Model Delft3D- FLOW adalah pemodelan hidrodinamika yang mensimulasikan dinamika aliran yang dipengaruhi oleh pasang surut dan kondisi meteorologis. Persamaan pembangun 
model hidrodinamika 2D pada flow model diatur berdasarkan persamaan kontinuitas dan momentum pada sumbu $-x$ dan $-y$ pada grid curvilinier. Sedangkan Delft3D-Wave adalah sistem yang merupakan bagian dari Delft3D yang berfungsi untuk mensimulasikan perambatan atau transformasi gelombang yang dihasilkan di perairan pantai namun dapat juga diterapkan di perairan dalam, menengah dan dangkal (Fahmi, M. \& Hafli, T. M., 2019). Formulasi persamaan pembangun pada Delft3D-FLOW dapat dilihat pada Persamaan 1 (af) yang merupakan persamaan momentum dan persamaan kontinuitas, sedangkan persamaan yang mengatur model Delft3D-WAVE adalah persamaan kesetimbangan spektrum gelombang (Persamaan 2).

a. Persamaan momentum dalam arah horizontal

$$
\begin{gathered}
\frac{\partial \zeta}{\partial r}+\frac{u \partial u}{\sqrt{G \zeta \zeta} \partial \zeta}+\frac{v \partial u}{\partial \eta \sqrt{G \eta}}+\frac{\omega \partial u}{d+\zeta \partial \sigma}-\frac{V^{2} \sqrt{G \eta \eta}}{\sqrt{G \zeta \zeta} \sqrt{G \eta \eta}}+ \\
\frac{u v \sqrt{G \zeta \zeta}}{\sqrt{G \zeta \zeta} \sqrt{G \eta \eta}}-F v=\frac{1}{\rho 0 \sqrt{G \zeta \zeta}} P \zeta+F \zeta+\frac{1}{(d+\zeta)^{2}} v \frac{\partial u}{\partial \sigma}+M \zeta \\
\frac{\partial \zeta}{\partial r}+\frac{u \partial u}{\sqrt{G \zeta \zeta} \partial \zeta}+\frac{v \partial u}{\partial \eta \sqrt{G \eta}}+\frac{\omega \partial u}{d+\zeta \partial \sigma}-\frac{u v \sqrt{G \eta \eta}}{\sqrt{G \zeta \zeta} \sqrt{G \eta \eta}}+ \\
\frac{V^{2} \sqrt{G \zeta \zeta}}{\sqrt{G \zeta \zeta} \sqrt{G \eta \eta}}-F v=\frac{1}{\rho 0 \sqrt{G \zeta \zeta}} P \zeta+F \zeta+\frac{1}{(d+\zeta)^{2}} v \frac{\partial u}{\partial \sigma}+M \zeta
\end{gathered}
$$

b. Persamaan Kontinuitas

$$
\frac{\partial \zeta}{\partial r}+\frac{1 \partial[(d+\zeta) U \sqrt{G \eta \eta}]}{\sqrt{G \zeta \zeta} \sqrt{G \eta \eta} \partial \zeta}+\frac{1 \partial[(d+\zeta) V \sqrt{G \zeta \zeta}]}{\sqrt{G \zeta \zeta} \sqrt{G \eta \eta} \partial \eta}=(d+\zeta) Q
$$

Dengan $U$ dan $V$ dirata-ratakan terhadap kedalaman:

$$
\begin{aligned}
& U=\frac{1}{d+\zeta} \int_{4}^{6} u d z=\int_{-1}^{0} u d \sigma \\
& V=\frac{1}{d+\zeta} \int_{4}^{6} v d z=\int_{-1}^{0} v d \sigma
\end{aligned}
$$

Dengan $Q$ menunjukan faktor per unit area:

$$
Q=H \int_{-1}^{0}(\text { qin }- \text { qout }) d \sigma+P-E
$$

c. Persamaan Spektrum Gelombang

$$
\frac{\partial}{\partial t} N+\frac{\partial}{\partial x} c x N+\frac{\partial}{\partial y} c y N+\frac{\partial}{\partial \sigma} c \sigma N+\frac{\partial}{\partial \theta} c \theta N=\frac{S}{\sigma}
$$

keterangan:

$\sqrt{G \zeta \zeta}=$ koefisien transformasi curvalinier menjadi koordinat persegi [m], $\sqrt{G \eta \eta}=$ koefisien transformasi curvalinier menjadi koordinat persegi [m], 


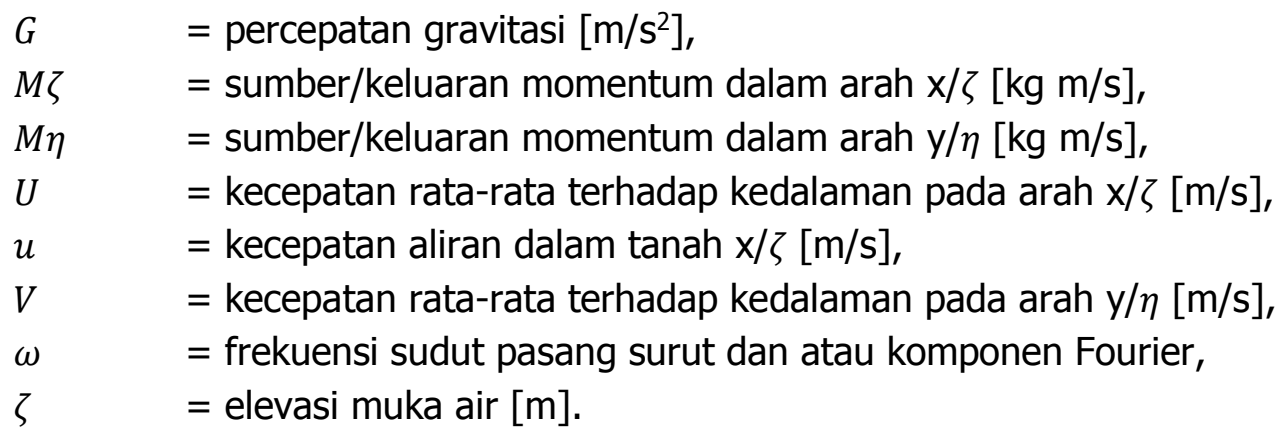

\section{METODOLOGI PENELITIAN}

\subsection{Lokasi Penelitian}

Lokasi untuk penelitian ini dilakukan di kawasan Pelabuhan Tanjung Adikarto yang terletak di Desa Karangwuni Kabupaten Kulon Progo Provinsi Daerah Istimewa Yogyakarta (DIY) seperti pada Gambar 1.

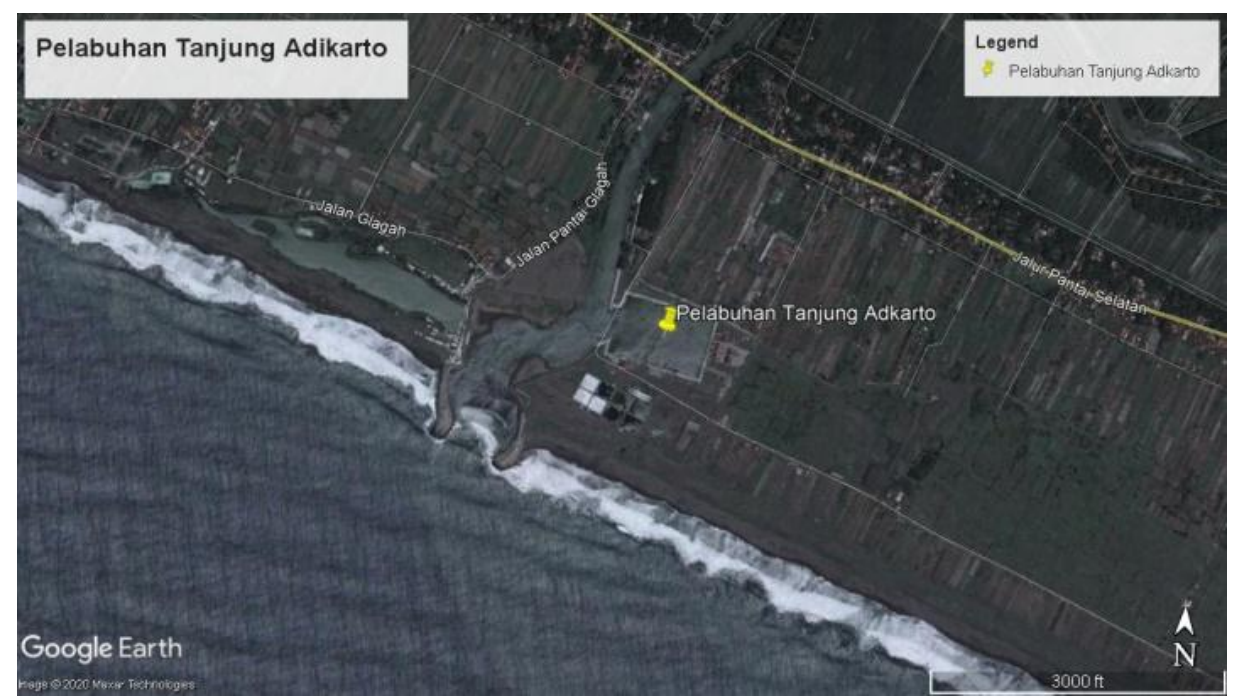

Gambar 1. Lokasi pelabuhan Tanjung Adikarto (Sumber: Google Earth, 2020)

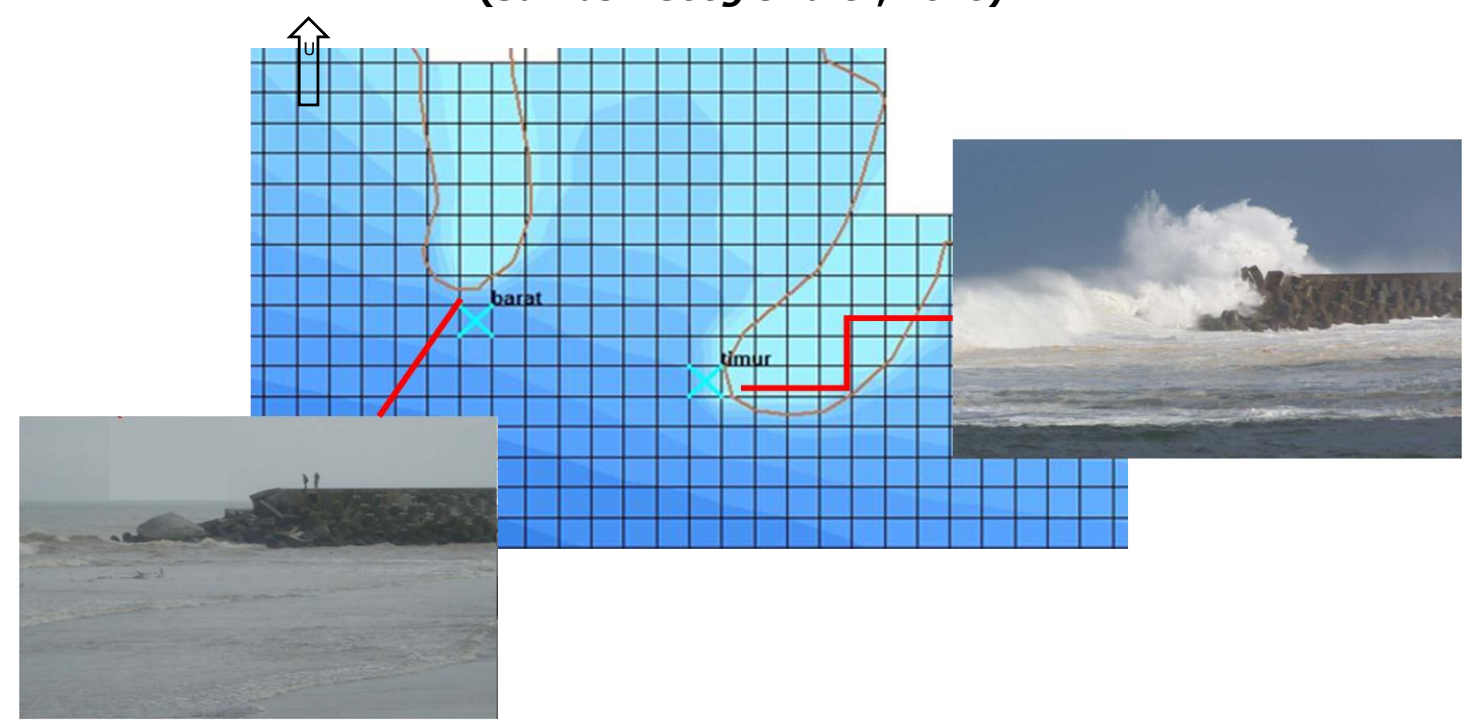

Gambar 2. Kondisi pemecah gelombang sisi barat dan sisi timur (Sumber: Bhakty, T. E., 2015) 


\section{Karakteristik Gelombang Laut Pada Rencana Pembangunan Breakwater \\ di Pelabuhan Tanjung Adikarto}

Gambar 2 merupakan gambaran kondisi pemecah gelombang saat ini, dimana bagian kepala dari breakwater sisi barat mengalami kerusakan dan juga beberapa lapis lindung (tetrapod) mengalami keruntuhan. Gelombang tinggi hingga mencapai $2 \mathrm{~m}$ juga menghantam breakwater sisi timur yang lama kelamaan dapat menyebabkan kerusakan di bagian kepala maupun lapis lindungnya. Konstruksi untuk desain review breakwater yang dibuat pada tahun 2011 ini juga harus terhenti pada tahun 2012.

Analisis dan evaluasi kerusakan breakwater yang dilakukan Project Yogya Team dan disupervisi oleh TU Delft dalam laporan Project Yogya pada tahun 2016 menyatakan berdasarkan kerusakan yang terjadi pada periode setelah konstruksi tahun 2012, breakwater dengan desain review 2011 kemungkinan besar tidak akan bertahan sesuai umur desain perencanaannya. Terdapat banyak tetrapod yang berpindah yang menyebabkan lapisan inti breakwater tidak terlindungi karena kurangnya lapisan pelindung yang tepat. Selain itu, breakwater yang ada saat ini tidak dapat melindungi pelabuhan dari gelombang tinggi. Pintu masuk pelabuhan tidak aman karena masih terdapat gelombang yang terlalu tinggi untuk dilalui kapal penangkap ikan. Gelombang tinggi ini juga masih bergerak jauh masuk ke pelabuhan.

\subsection{Model Setup}

Pemodelan hidrodinamika pada penelitian ini menggunakan software Delft3D. Modul Delft3D yang digunakan yaitu Delft3D-FLOW untuk simulasi hidrodinamika dan Delft3D-Wave untuk simulasi transformasi gelombang. Grid yang digunakan pada pemodelan yaitu curvilinier grid yang berukuran panjang sebesar \pm 1.310 meter dengan lebar sebesar \pm 1.260 meter pada bagian sebelah barat dan \pm 680 meter pada bagian sebelah timur dengan interval grid 20 meter. Pemodelan gelombang di sekitar breakwater dilakukan dalam dua skenario yaitu kondisi desain eksisting (desain review 2011) dan desain perencanaan penyempurnaan (desain review 2013). Simulasi pemodelan dilakukan masing-masing dengan durasi selama 30 hari yaitu pada bulan Juli 2018 untuk mewakili musim timur dan bulan Januari 2018 untuk mewakili musim barat dengan interval waktu 60 menit. Pada penelitian ini nilai awal debit sungai tidak menjadi masukan dalam pemodelan.

\subsection{Data Penelitian}

Data yang digunakan pada penelitian ini adalah data sekunder. Untuk memodelkan kondisi hidrodinamika dan juga gelombang di area studi maka terlebih dahulu diperlukan data batimetri di sekitar Tanjung Adikarto. Data batimetri yang digunakan pada penelitian ini diperoleh dari peta batimetri pada studi terdahulu yang dilakukan oleh Prawira (2008) dalam Pakpahan, I. B. (2013). Peta batimetri ini kemudian dikombinasikan dengan garis pantai pada kondisi terkini dari Google Earth. Gambar 3 (a) merupakan data batimetri yang digunakan sebagai input pada pemodelan hidrodinamika dan pemodelan transformasi gelombang untuk kondisi eksisting yaitu desain review tahun 2011. Gambar 3 (b) merupakan dan peta layout desain perencanaan penyempurnaan bangunan pemecah gelombang yaitu desain review yang dibuat tahun 2013 (Pakpahan, I. B., 2013).

Selain data batimetri juga diperlukan data pasang surut untuk simulasi dengan menggunakan Delft3d-FLOW. Data pasang surut yang digunakan pada pemodelan Delft3dFLOW didapatkan dari komponen pasang surut dengan menggunakan Delft Dashboard. Komponen pasang surut ini menjadi input pada setiap batas terbuka area model, yaitu pada batas bagian barat, selatan, dan timur.

Data angin diperoleh dari ECMFW (European Centre for Medium-Range Weather Forecasts) yang merupakan hasil model re-analisis. Data kecepatan dan arah angin dari ECMWF 
memiliki interval waktu enam jam pada ketinggian $10 \mathrm{~m}$ di atas permukaan laut. Data angin yang menjadi masukan model diasumsikan konstan berdasarkan angin dominan yang bertiup pada bulan Januari untuk mewakili kondisi musim barat dan bulan Juli untuk mewakili kondisi musim timur.
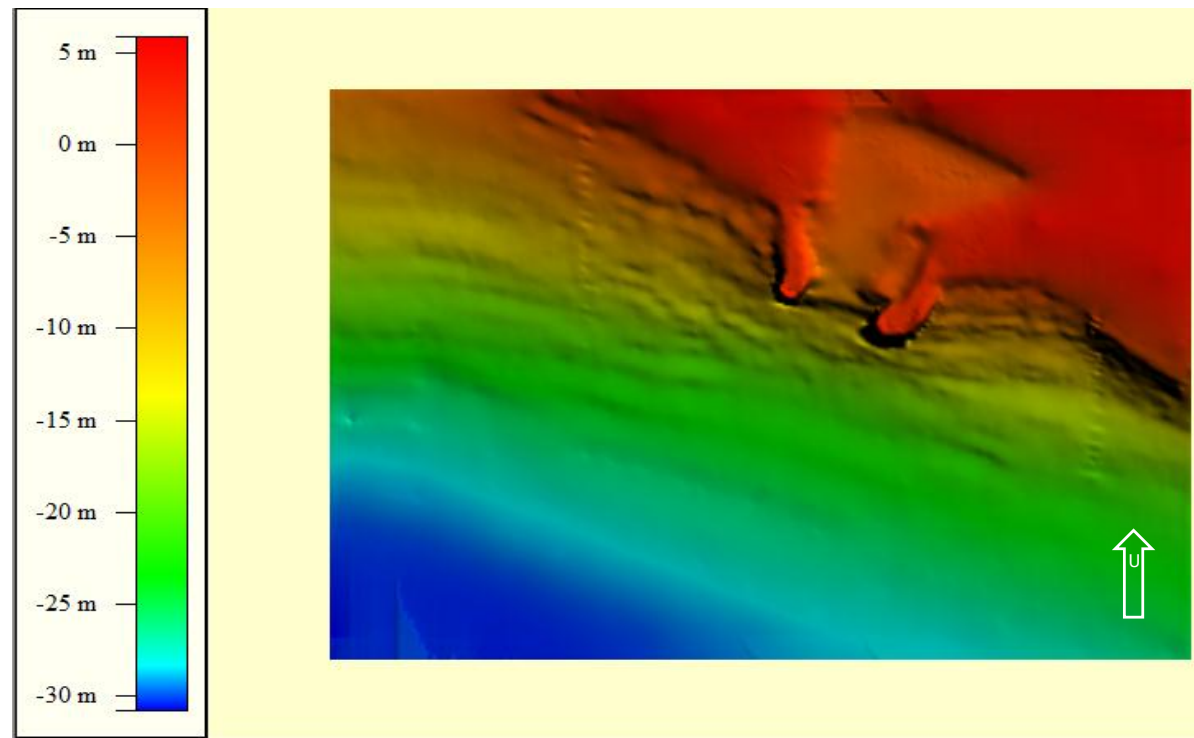

(a)

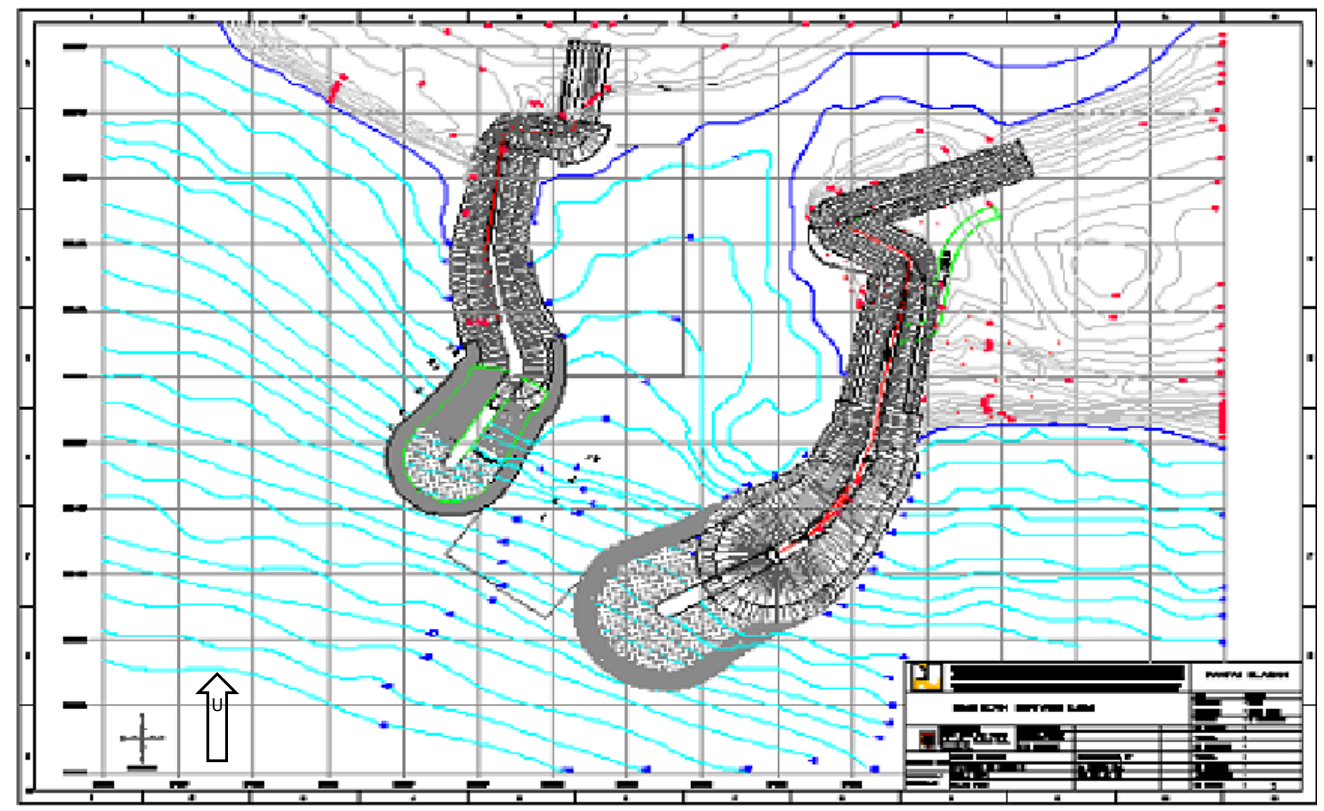

(b)

Gambar 3. Batimetri Pelabuhan Tanjung Adikarto: (a) kondisi eksisting, (b) peta batimetri dengan rencana desain penyempurnaan bangunan pemecah gelombang (Sumber: Pakpahan, I. B., 2013)

Data gelombang diperlukan juga sebagai nilai awal pada pemodelan transformasi gelombang. Data yang digunakan yaitu data gelombang hasil hindcasting pada penelitian yang dilakukan oleh Chrysanti, et al. (2019) dengan menggunakan data angin dari NOAA selama 10 tahun. Tinggi gelombang signifikan yang menjadi nilai awal pada pemodelan yaitu sebesar 1,7 meter dengan perioda gelombang sebesar 5,7 detik. Gelombang swell pada pemodelan yang dilakukan pada penelitian ini tidak diperhitungkan. 


\section{ANALISIS DAN PEMBAHASAN}

\subsection{Validasi Hasil Pemodelan}

Elevasi muka air laut yang didapatkan dari simulasi model dengan menggunakan Delft3D divalidasi dengan menggunakan dan data elevasi muka air laut dari Badan Informasi Geospasial (BIG) selama 15 hari pada bulan Juli. Titik pengambilan data untuk validasi terletak pada -7,9200 LS dan 110,0766 BT. Gambar 4 merupakan grafik perbandingan elevasi muka air laut hasil pemodelan dengan data dari BIG. Dari Gambar 4 terlihat elevasi muka air laut hasil model hampir sama besarnya dengan data elevasi muka air laut dari BIG, meskipun terdapat selisih $\pm 30 \mathrm{~cm}$ namun model sudah dapat dikatakan cukup baik dan dapat menggambarkan kondisi sebenarmya di lapangan.

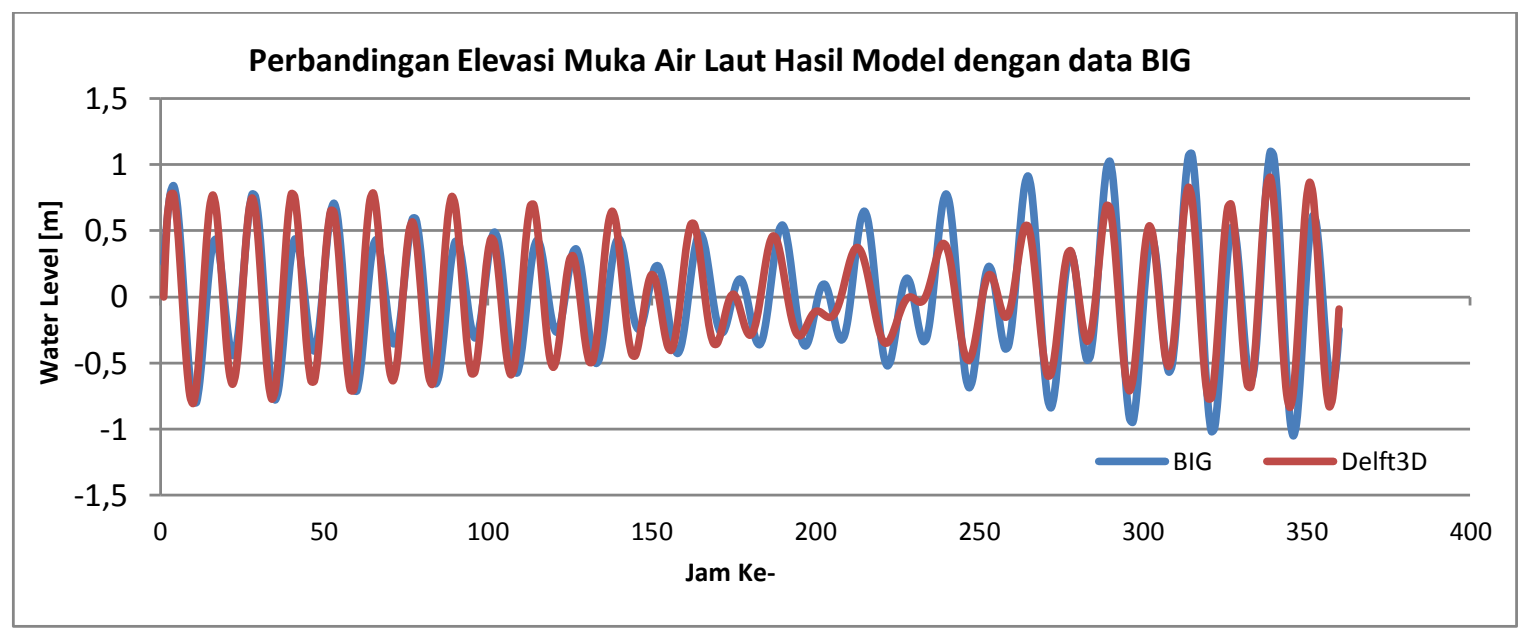

Gambar 4. Perbandingan elevasi muka air hasil pemodelan dengan data BIG

\subsection{Hasil Pemodelan Hidrodinamika}

Hasil simulasi kecepatan arus pada saat musim barat dan musim timur untuk kondisi eksisting (desain review 2011) dan kondisi perencanaan (desain review 2013) menunjukan kecepatan arus di sekitar kepala breakwater berkisar $0 \mathrm{~m} / \mathrm{s}$ sampai 0,45 m/s; sedangkan di area bagian dalam pelabuhan bisa mencapai lebih dari $0,6 \mathrm{~m} / \mathrm{s}$. Arah datang arus pada musim barat dan musim timur relatif sama, yaitu pada saat surut menuju pasang arah arus bergerak dari arah barat dan saat pasang menuju surut arus bergerak dari arah timur. Namun kecepatan arusnya lebih besar saat musim barat dibandingkan saat musim timur.

Pada saat pasang arus bergerak memasuki pelabuhan, kemudian saat pasang menuju surut arus mulai bergerak keluar dari pelabuhan dan kemudian bertemu dengan arus di luar pelabuhan yang bergerak ke arah barat saat musim timur dan ke arah timur saat musim barat, akibatnya di area depan mulut breakwater terbentuk turbulensi. Turbulensi juga terlihat di bagian timur breakwater sisi timur pada saat musim barat. Kecepatan arus di bagian kepala breakwater saat musim timur berkisar antara 0,25-0,45 m/s; sedangkan saat musim barat berkisar antara 0,1-0,3 m/s.

Kecepatan arus yang masuk ke dalam mulut pelabuhan pada kondisi desain rencana relatif lebih kecil jika dibandingkan dengan kondisi desain eksisting saat kondisi menuju surut. Dari hasil pemodelan untuk kondisi desain eksisting maupun rencana, terlihat adanya turbulensi di area dalam pelabuhan dan juga di bagian mulut pelabuhan. Hasil pemodelan Delft3DFLOW yang menunjukan kecepatan dan arah arus pada kondisi eksisting dan kondisi rencana saat kondisi pasang menuju surut dapat dilihat pada Gambar 5 dan Gambar 6. Kecepatan 
arus yang besar $(>0,7 \mathrm{~m} / \mathrm{s})$ dan bergerak sejajar pantai pada bagian barat Pantai Glagah dapat menyebabkan terjadinya erosi pada area tersebut.

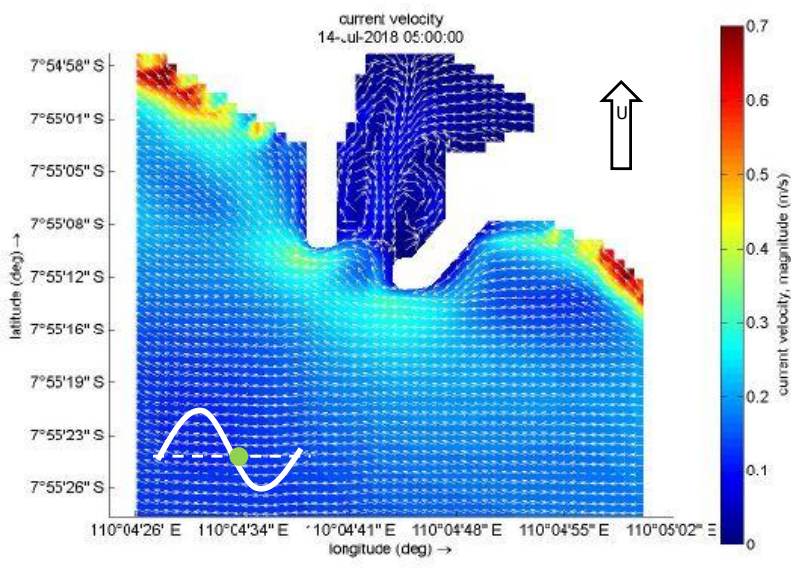

(a)

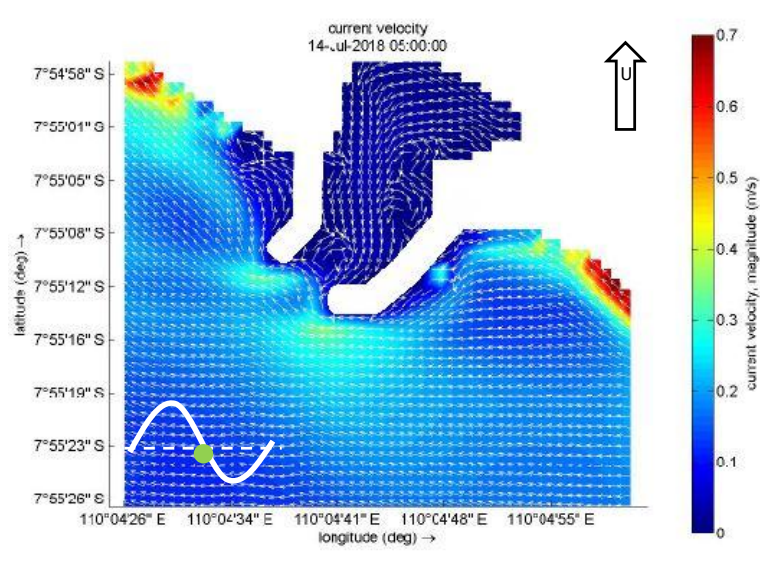

(b)

Gambar 5. Kecepatan arus saat musim timur: (a) kondisi eksisting, (b) kondisi rencana

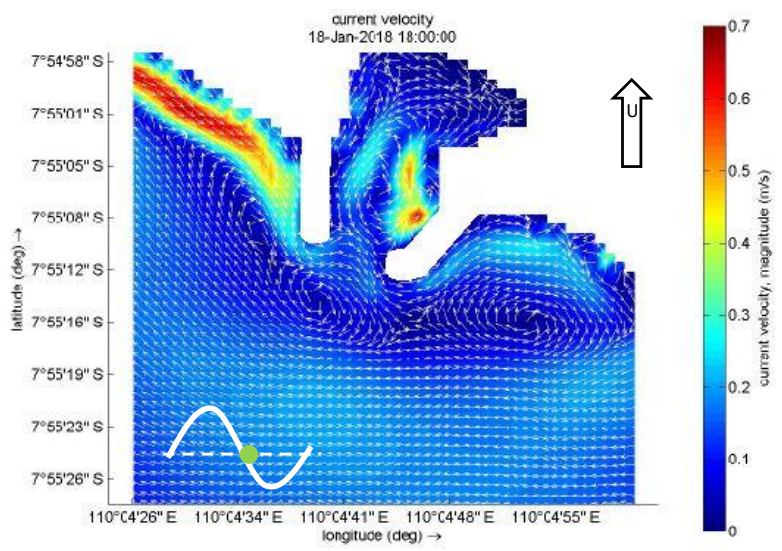

(a)

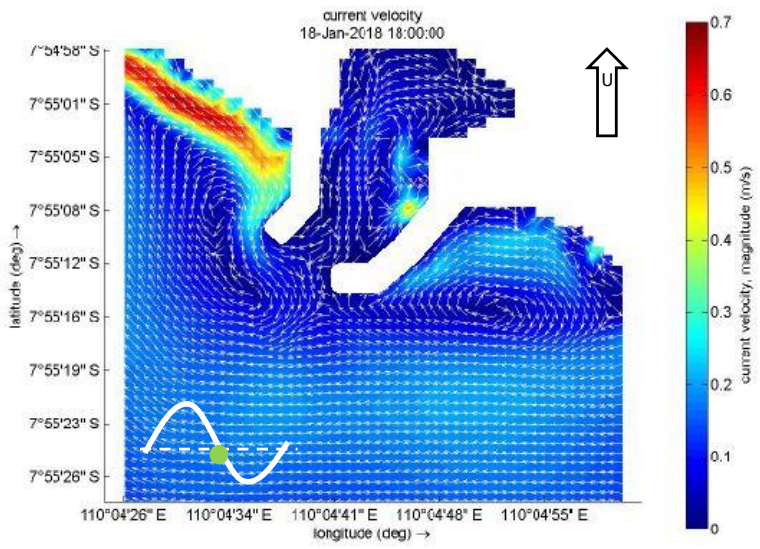

(b)

Gambar 6. Kecepatan arus saat musim barat: (a) kondisi eksisting, (b) kondisi rencana

\subsection{Hasil Pemodelan Gelombang}

Hasil simulasi pemodelan gelombang pada kondisi eksisting dan rencana saat musim timur dan musim barat dapat dilihat pada Gambar 7 dan Gambar 8. Pada saat musim timur gelombang datang dari arah tenggara, sedangkan saat musim barat gelombang datang dari arah barat. Pada kondisi eksisting saat musim timur; tinggi gelombang di bagian kepala breakwater sisi barat dan sisi timur mencapai 1,5 m; sedangkan saat musim barat tinggi gelombang yang menghantam bagian kepala breakwater lebih tinggi yaitu mencapai $1,8 \mathrm{~m}$. Pada saat musim barat juga terlihat tinggi gelombang sebesar $1 \mathrm{~m}$ berada di area dalam pelabuhan pada kondisi desain eksisting maupun kondisi desain rencana. Hal ini disebabkan karena saat musim barat arah gelombang datang yang datang dari arah barat mengalami refraksi dan difraksi sehingga gelombang tinggi tetap masuk ke mulut pelabuhan. Tinggi gelombang di mulut pelabuhan masih berkisar antara 1,2-1,6 m; hal ini tidak aman bagi kapal penangkap ikan yang akan memasuki pelabuhan karena gelombang yang terlalu tinggi.

Tinggi gelombang pada kondisi desain eksisting dan kondisi desain rencana ditinjau pada titik 1 yang berada di bagian depan kepala breakwater sisi barat, titik 2 yaitu titik pengamatan yang berada di bagian depan kepala breakwater sisi timur, titik 3 yaitu titik pengamatan yang berada pada mulut pelabuhan, dan titik 4 yaitu titik yang berada di bagian 
dalam pelabuhan. Grafik perbandingan tinggi gelombang di 4 titik pengamatan pada kondisi eksisting dan kondisi rencana pada saat musim barat dapat dilihat pada Gambar 9 dan Gambar 10.

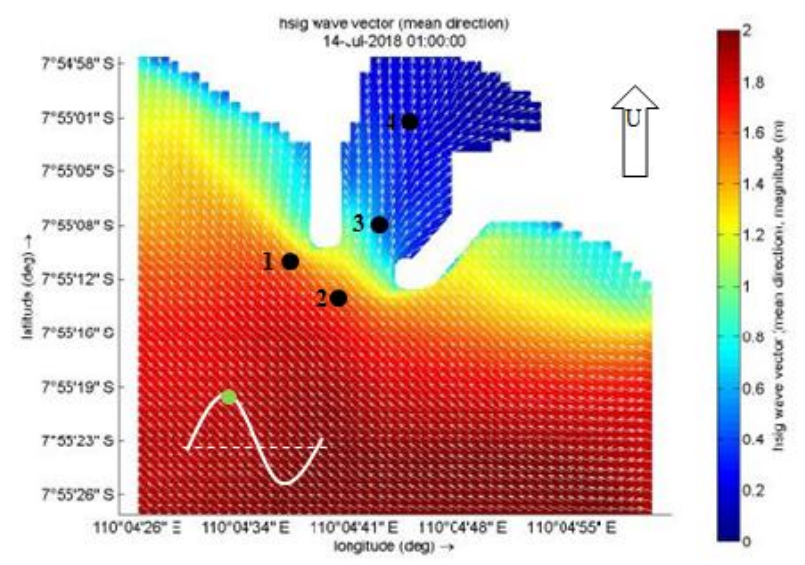

(a)

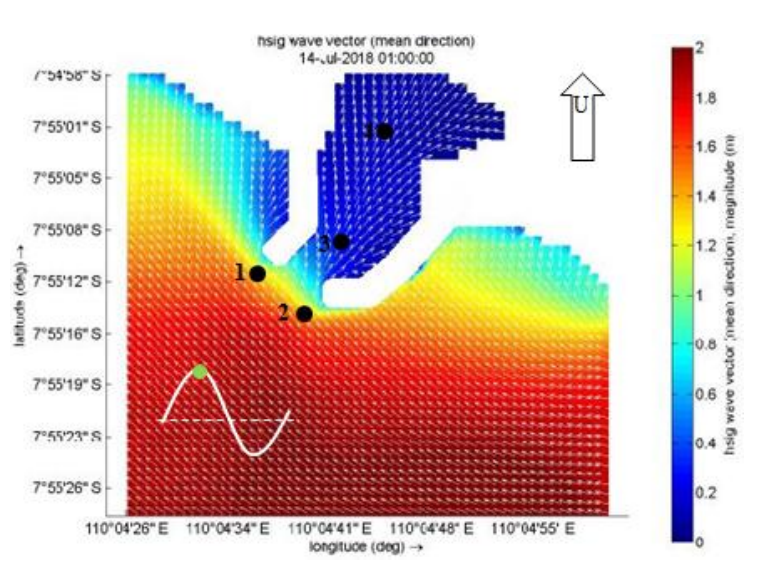

(b)

Gambar 7. Tinggi gelombang saat musim timur: (a) kondisi eksisting, (b) kondisi rencana

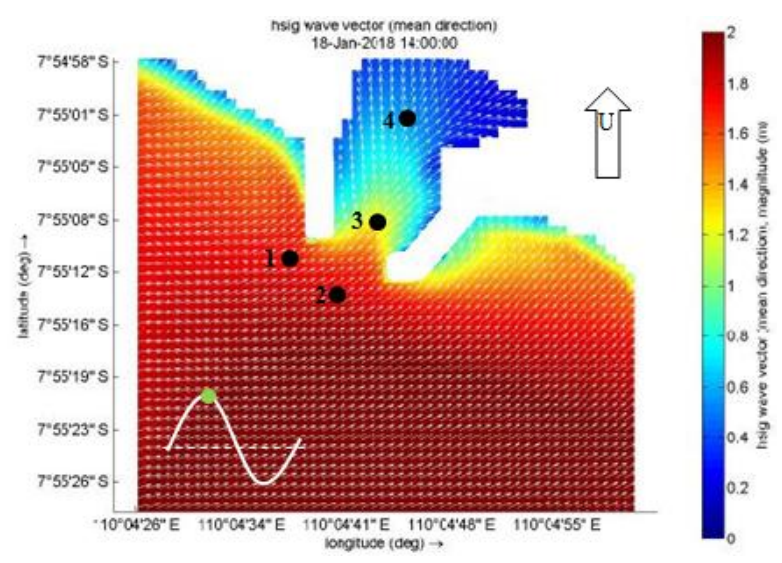

(a)

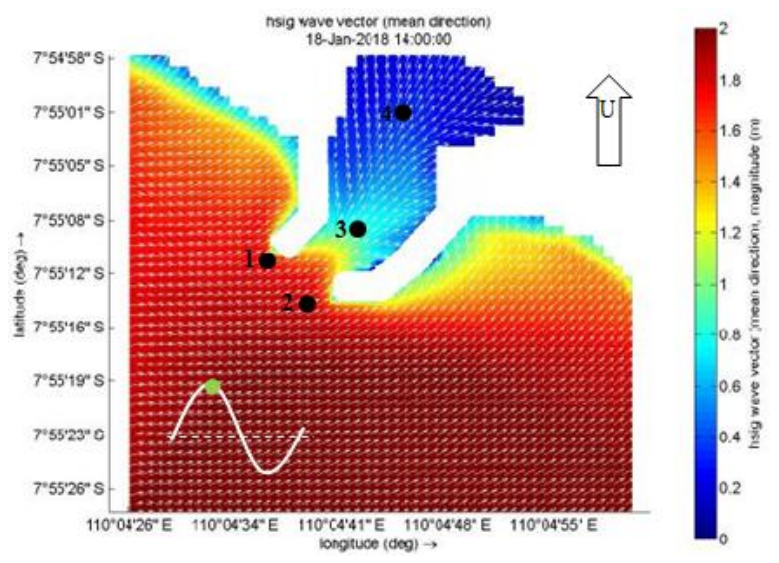

(b)

Gambar 8. Tinggi gelombang saat musim barat: (a) kondisi eksisting, (b) kondisi rencana

Berdasarkan grafik pada Gambar 9 dan Gambar 10 terlihat tinggi gelombang pada saat musim barat relatif lebih besar dibandingkan saat musim timur. Setelah adanya penambahan panjang pada breakwater sisi barat dan timur, gelombang tinggi yang datang telah dapat tereduksi. Namun gelombang tinggi hingga 1,8 m masih menghantam bagian kepala breakwater baik breakwater sisi barat maupun sisi timur pada musim barat dan juga saat musim timur. Breakwater desain rencana mampu mereduksi tinggi gelombang sebesar $79,44 \%$ pada musim timur dan $50,64 \%$ pada musim barat di mulut pelabuhan. Sedangkan tinggi gelombang di bagian dalam pelabuhan telah tereduksi hingga $89,18 \%$ pada musim timur dan $79,62 \%$ pada musim barat. Meskipun begitu gelombang tinggi di mulut pelabuhan masih belum aman untuk kapal penangkap ikan memasuki area pelabuhan. 
Fitri Suciaty, Hasan Murtadho

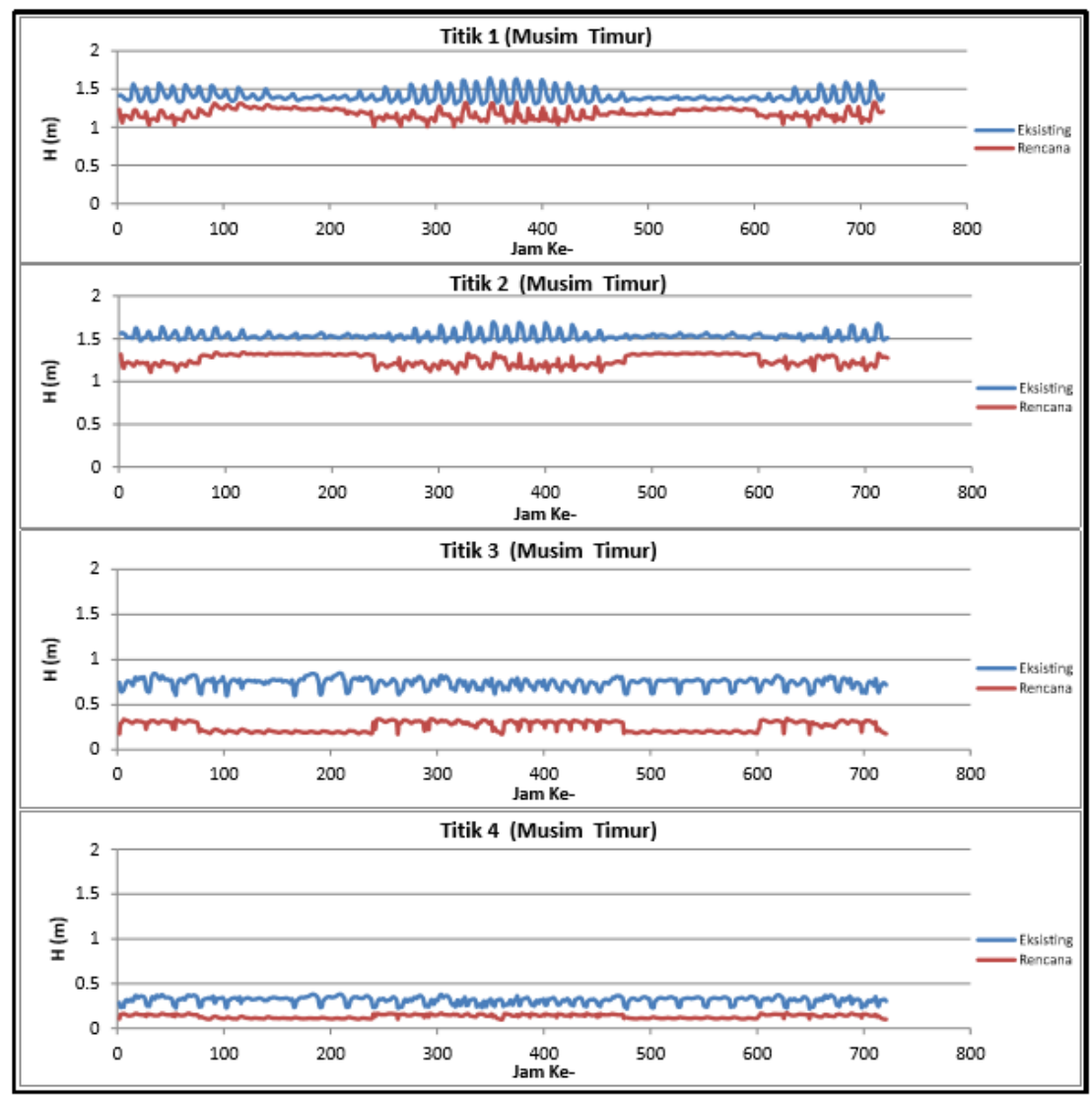

Gambar 9. Perbandingan tinggi gelombang di titik 1, 2, 3, dan 4 saat musim timur

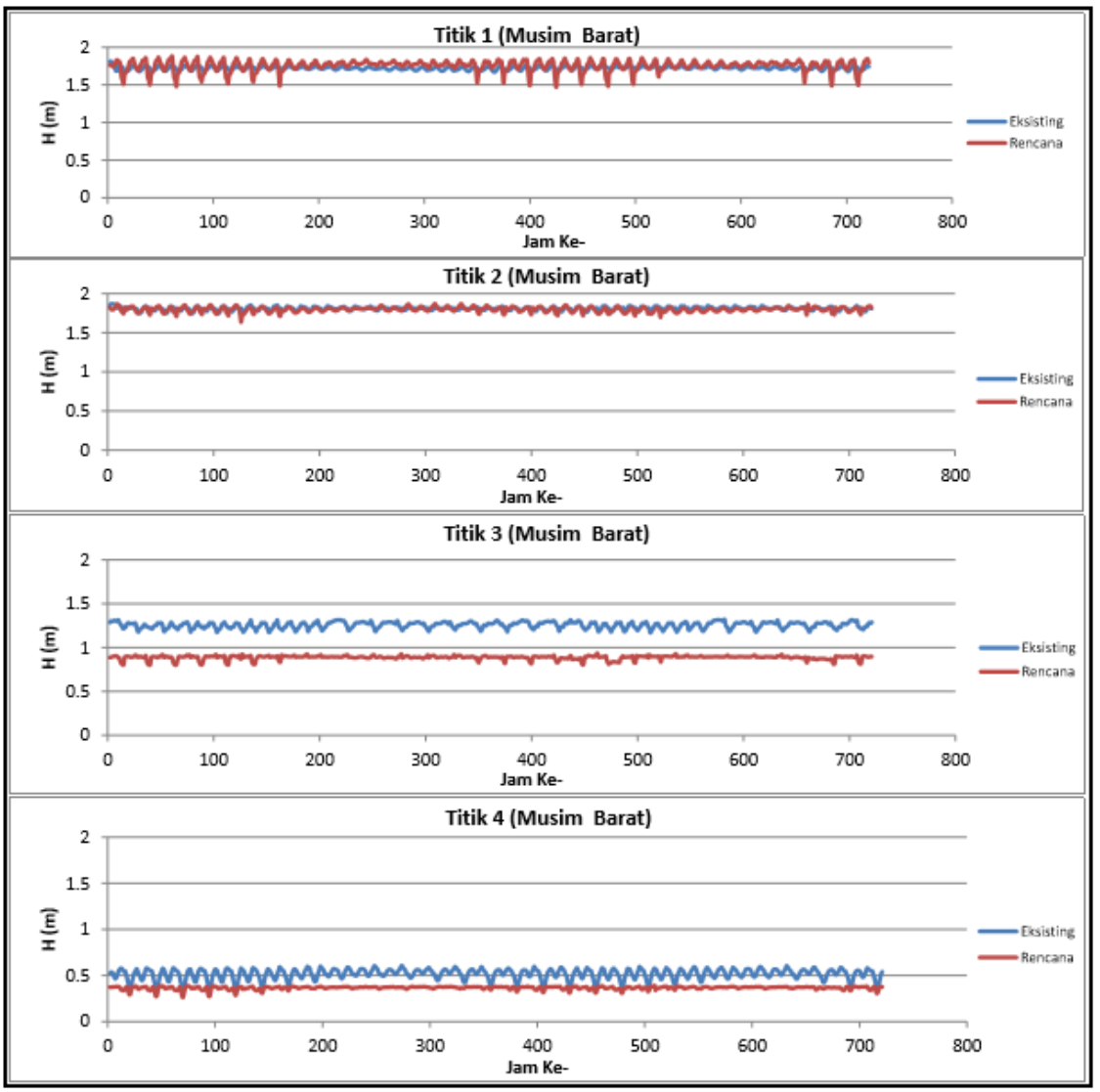

Gambar 10. Perbandingan tinggi gelombang di titik 1, 2, 3, dan 4 saat musim barat

RekaRacana: Jurnal Teknik Sipil - 213 


\section{Karakteristik Gelombang Laut Pada Rencana Pembangunan Breakwater \\ di Pelabuhan Tanjung Adikarto}

\section{KESIMPULAN}

Berdasarkan hasil pemodelan hidrodinamika dan pemodelan transformasi gelombang dapat ditarik kesimpulan sebagai berikut:

1. Kecepatan arus di sekitar kepala breakwater relatif kecil yaitu berkisar $0 \mathrm{~m} / \mathrm{s}$ sampai 0,45 $\mathrm{m} / \mathrm{s}$ baik saat musim barat maupun musim timur.

2. Terdapat variasi musiman tinggi gelombang pada saat musim barat dan timur, dimana tinggi gelombang saat musim barat relatif lebih besar dibandingkan saat musim timur.

3. Hasil pemodelan Delft3D-Wave menunjukan tinggi gelombang di sekitar kepala breakwater sebesar $\pm 1,5$ meter di musim timur dan $\pm 1,8$ meter. Dengan tinggi gelombang dan kecepatan arus yang kecil, kerusakan yang terjadi pada kepala breakwater dapat dikatakan didominasi oleh pengaruh gelombang.

4. Desain review breakwater tahun 2013 dapat mereduksi tinggi gelombang lebih baik dibandingkan desain breakwater tahun 2011 dengan persentase reduksi tinggi gelombang $89,18 \%$ pada musim timur dan $79,62 \%$ pada musim barat.

\section{DAFTAR RUJUKAN}

Bhakty, T. E. (2015). Permasalahan Pemecah Gelombang (Studi Kasus: Glagah, Kabupaten Kulon Progo). Tugas Akhir. Yogyakarta: Jurusan Teknik Sipil Fakultas Teknik Universitas Janabadra.

Chrysanti, A., Adityawan, M. B., Widyaningtyas, Yakti, B. P., Nugroho, J., Zain, K., Haryanto, I., Sulaiman, M., Kurniawan, A. \& Tanaka, H. (2019). Prediction of shoreline change using a numerical model: case of the Kulon Progo Coast, Central Java. The 2nd Conference for Civil Engineering Research Networks (ConCERN-2 2018) (hal. 1-8). Bandung: MATEC Web of Conferences 270, 04023 (2019).

Deltares. (2014). Delft3D-Flow, Simulation of multi-dimensional hydrodynamic flows and transport phenomena, including sediments. User Manual: Hydro-Morphodynamics. Version: 3.15. SVN Revision: 34158. Delft: Deltares.

Fahmi, M. \& Hafli, T. M. (2019). Simulasi Numerik Perubahan Morfologi Pantai Akibat Konstruksi Jetty pada Muara Lambada Lhok Aceh Besar Menggunakan Delft3D. Jurnal Teknik Sipil, 8(2), 50-59.

Pakpahan, I. B. (2013). Analisis Transpor Sedimen Menyusur Pantai dengan Menggunakan Metode Grafis pada Pelabuhan Perikanan Tanjung Adikarta. Jurnal Maroso, 1(1), 714.

Project Yogya Team. (2016). Main Report - Project Yogya: Recommendations for the continued pursuit of a safe, durable and sustainable Tanjung Adikarto Port. Theses. Yogyakarta: Project Yogya, BBWS Serayu Opak \& TU Delft.

Technologies, M. (2020, Juni 30). Google. Dipetik Juni 30, 2020, dari Google Earth: https://earth.google.com/web/search/pelabuhan+tanjung+adikarto/@-

7.916395,110.0851331,9.58483826a,1045.27800886d,35y,0h,45t,0r/data=CoUBGlsS VQolMHgyZTdhZTNhM2I4MDVhM2QzOjB4NWI2MzhlOWIxYzNmMzk2Nhkm32xzY6ofw CGnExrScoVbQCoacGVsYWJ1aGFuIHRhbmp1bmcgYWRpa2FydG8 